\title{
Editorial
}

\section{Annihilation of Masks: Undoing Hierarchy and Patriarchy in South Asian Diasporic Communities}

\author{
Anuradha Vikram \\ Otis College of Art and Design, Los Angeles, CA, UsA \\ anu@curativeprojects.net
}

The appearance of South Asians in contemporary American art history is partial at best, fragmented by categorizations that insufficiently describe the multiple realities of cultural experience. The picture of diasporic culture is faded by our historically undocumented status. Labourers immigrating prior to the 1965 Immigration and Nationality Act were made to disappear into permissible, if segregated, ethnic communities or be criminalized for maintaining a culture characterized by authorities as implicitly deviant or queer. Not coincidentally, the late 196os was also the beginning of LGBTQ legalization in the United States 1 - a process which, like inclusion and recognition of South Asian Americans, remains incomplete and, like discrimination against South Asians, hinges on a rhetoric of unfamiliarity as implicitly unnatural. Unable to function above board as intersectionally South Asian, artists in our community are dissected by arts institutions into "Muslim artist," "African-American artist," "media artist," or "queer artist" rather than "Bangla artist," "Goan artist," "anticaste artist," or simply "artist." These practices are descended from Muslim, Hindu, Christian, Dalit, or Adivasi traditions, and formed in the US through institutions of culture and higher learning — though not always MFA programs

1 "A Timeline of Lesbian, Gay, Bisexual, and Transgender History in the United States," LGBT History Materials, GSAFE, accessed 23 April 2019, https:/www.gsafewi.org/wp-content/ uploads/US-LGBT-Timeline-UPDATED.pdf. 
or museums. The following text will discuss artists such as Hasan Elahi, a research-based artist working with visualization now based at George Mason University, and Thenmozhi Soundararajan, who developed her visual art practice while working as a filmmaker and activist. What do these alternative frames of reference bring to the discussion of American art? Can we use these practices as a lens to anticipate the future of artistic production?

As we approach the 2020 US presidential election, California senator Kamala Harris is the first American woman of South Asian heritage who appears to be a serious contender for a major party nomination. Her ascent reflects a number of interesting developments in the political condition of the diaspora. First, and impossible to overstate, is Senator Harris' mixed parentage, of Jamaican and Indian descent. Her visibility within the US political landscape, where South Asian liberals are active as public attorneys but less so as elected representatives, is no doubt due to her identification with African American political movements: both the Civil Rights era that brought her idealistic, immigrant parents together in the $1960{ }^{2}{ }^{2}$ and the neoliberal "post-black" ${ }^{3}$ Obama era with its quieter, but no less dramatic tectonic shifts. Harris' unabashed embrace of her Black heritage is a refreshing change from what has generally been a tendency to kowtow to white conservative values in a desperate bid for assimilation (as per former Louisiana governor Bobby Jindal, former ambassador to the UN Nikki Haley, or pundit Dinesh D'Souza). Even so, Harris has established a "law and order" profile and a reputation for not going far enough to dismantle racist policing and carceral systems.

If Harris represents a generation born of Black radical love, her politics are the assimilationist ones of upwardly mobile, socially aspirational immigrants of colour. Additionally, her visibility in the American landscape is overwhelmingly focused on her African American parentage rather than her South Asian or immigrant heritage. Her ascent illustrates a conundrum that

2 Casey Tolan, "How Kamala Harris' Immigrant Parents Shaped Her Life-and Her Political Outlook," The Mercury News, 10 February 2019, https://www.mercurynews.com/2019/o2/10/ kamala-harris-president-parents-shyamala-gopalan-donald-harris-berkeley/.

3 "Post-black" is a term that emerged in the 199os to describe art and cultural practices that combined critical race analysis with postmodernism. First coined to describe contemporary art and popularized by Thelma Golden at the Studio Museum of Harlem in the 2001 exhibition Freestyle, "post-black" in the Obama era came to refer to a conception of Blackness that was individualized rather than collective. "Frequency," Studio Museum Harlem, accessed 23 April 2019, https://www.studiomuseum.org/exhibition/frequency; "Toure Discusses What It Means To Be Post-Black," interview by Michele Norris, All Things Considered, NPR, 27 September 2011, audio, 6:31, https://www.npr.org/2011/og/27/140854965/toure-discusses-what-it-means-to-be -post-black. 
our community of artists also faces-in which sustenance, rewards, and opportunity confer within established institutions to those faces of colour who are easily categorizable, or serve systems that marginalize and criminalize our perspectives, while artists and culture workers who seek to subvert and ultimately dismantle these failing systems lack organized alternatives. As activist and historian Sarah Schulman has said in relation to queer assimilation, "those of us who most resemble the dominant group, and with whom they are most comfortable, are admitted into the realm of recognition."4 The rest of us struggle to move freely in a condition of incomplete liberation.

Homi K. Bhabha details how the imposition of European systems and institutions on the landscape of overseas colonies, left intact but evacuated by the withdrawal of the colonial apparatus, creates the conditions for a new construction of difference that is "almost the same, but not quite." Invoking Frantz Fanon's "white mask" of assimilation, Bhabha, himself a professor at Harvard, describes presumably from experience how the colonized subject learns to disassociate from the self in order to more successfully reflect the expectations, and receive the praise, of white authority. ${ }^{6}$ Harris' record as a prosecutor was characterized by opposition to criminal justice reforms and wrongful conviction reviews that would have benefited African Americans most given their massive overrepresentation within the incarcerated population, and widespread police brutality against Black suspects. ${ }^{7}$ She is being rewarded with a chance at the Democratic nomination for President, following a model for personal advancement as an American woman of colour that is established by taking the heads of people of colour elsewhere, as through Barack Obama's two terms of ongoing remote warfare against swANA (Southwest Asian and North African) people in Afghanistan and Pakistan.

In the US circa 2019, similar examples of South Asian Americans in leadership proliferate. Rather than counteract the excesses and violations of the Trump era, we see examples like Vinod Khosla, billionaire founder of Sun Microsystems, fighting the California Coastal Commission tooth and nail to keep

4 Sarah Schulman, "1. I have no opinion as yet about a Democratic candidate, but I do have feelings about the gay aspect of the Buttigieg candidacy," Twitter Post, 17 April 2019, 4:40 AM, https://twitter.com/sarahschulman3/status/1118479397659578368.

5 Homi K. Bhabha, "Of Mimicry and Man: The Ambivalence of Colonial Discourse," in The Location of Culture (London, New York: Routledge, 1994), 122.

6 Bhabha, "Of Mimicry and Man," 126.

7 Lara Bazelton, “Kamala Harris Was Not a 'Progressive Prosecutor,” The New York Times, 17 January 2019, https://www.nytimes.com/2019/01/17/opinion/kamala-harris-criminal-justice. html. 
the public off the public beachfront adjacent to his estate; ${ }^{8}$ or Raj Rajaratnam and Rajat Gupta, still unrepentant for a massive insider trading scheme they engineered while the US was in fragile recovery from the bank-led 2008-09 economic collapse. ${ }^{9}$ Even within liberal enclaves like the humanities, representation tracks closely with class, as well as caste. Immigrants to the US from middle-class Indian families, like Bhabha and Gayatri Chakravorty Spivak, have popularized academic discourse around race and the subaltern, but South Asians of lower caste and class position are less often supported financially or interpersonally to speak on their own behalf through academic discourse.

Artists in the US are challenging the narrative of South Asian model minorities and proposing speculative alternatives that queer systems of control. They are using popular art forms like music and dance, craft media and techniques, and technological innovations to make their work. They include Hasan Elahi, a Bangladeshi American artist originally from Brooklyn and now based in Portland, Oregon, who makes use of the "poor image" that results from surveillance visualization technologies. The poor image, in Hito Steyerl's terminology, is the democratically liberated effigy of the formerly commoditized image that was subject to social control. ${ }^{10}$ Initially monitoring his own trajectories and actions as a target of FBI monitoring in the post-9/11 surveillance landscape, Elahi has recently been creating architectural-scale digital collages using borders and other liminal surveilled spaces as material. His work, which presents an overload of information as a screen that in fact reveals nothing, is emblematic of the in-between condition of the global South Asian American Muslim, whose smooth passage as a US citizen is as guaranteed as his incongruity in whitecoded spaces.

Kenyan-born, Toronto-raised Brendan Fernandes, currently based in Chicago, uses his training in Western classical and modern dance to create performances and art objects that infuse white aesthetics with African energies. Choreographing performances for spaces such as New York's High Line, the Guggenheim Museum rotunda, and Chicago's Graham Foundation, Fernandes considers the body as it meets resistance from the outside world (fig. 1). Frantz

Nellie Bowles, "Billionaire's Fight to Close Path to a California Beach Comes to a Dead End," The New York Times, 1 October 2018, https://www.nytimes.com/2018/10/o1/technology/ california-beach-access-khosla.html.

9 Andrew Ross Sorkin, "Rajat Gupta Is Unrepentant for His Crimes," The New York Times, 22 March 2019, https://www.nytimes.com/2019/03/22/business/dealbook/rajat-guptaunrepentant.html.

10 Hito Steyerl, "In Defense of the Poor Image," e-flux journal 10 (November 2009), https:// www.e-flux.com/journal/10/61362/in-defense-of-the-poor-image/. 


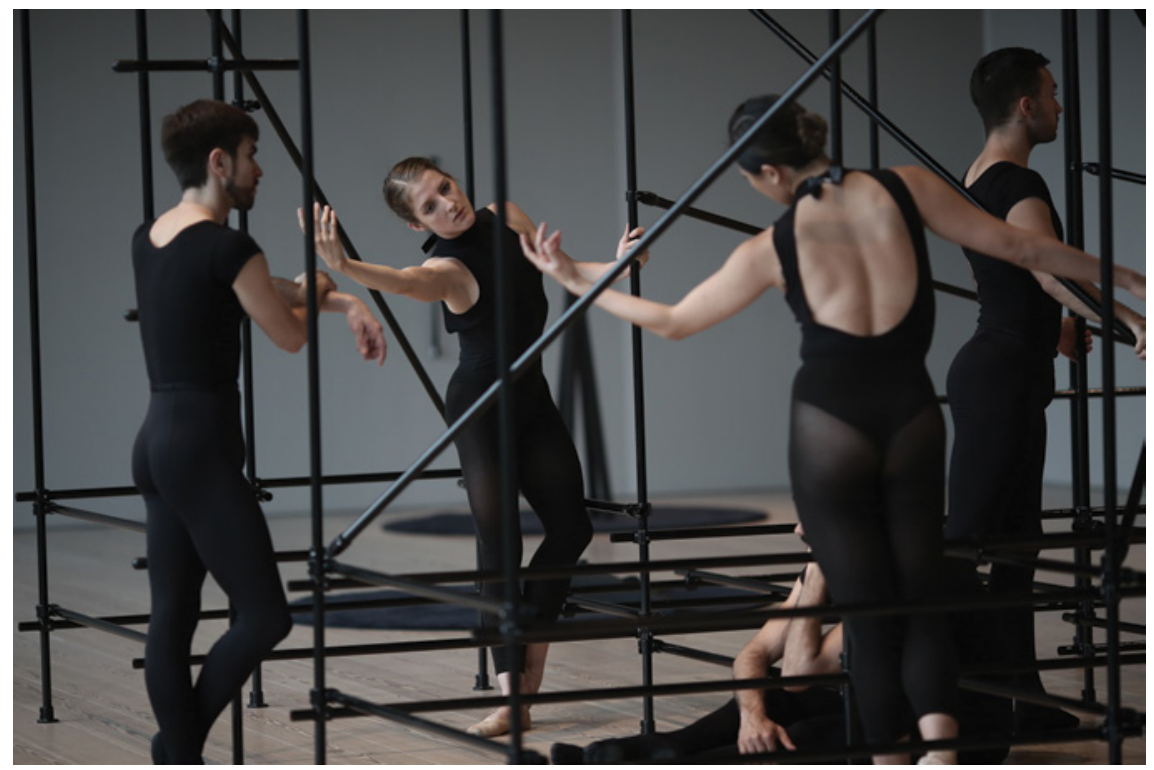

FIGURE 1 Brendan Fernandes, The Master and Form, June 7, 2019, performance, Whitney Biennial 2019. Performers pictured: Left to right: Mauricio Vera, Amy Saunder, Tiffany Mangulabnan, and Tyler Zydel. PHOTO BY PAULA COURT.

Fanon comes into play, in his consideration of how Black subjects must internalize the perceptions of white others in order to protect themselves from unintended consequences negotiated at the interface of skin. Riding a line between Giorgio Agamben's disassociated, ticcing celluloid gesture and Alva Noe's articulation of choreography as a system of social organization that takes its shape from the naturally occurring forms of dance, Fernandes responds to violence against his LGBTQ community such as the shooting at Pulse Nightclub in Orlando, Florida in 2016, and to the history of gendered and racialized violence that characterizes the colonial project.

LA-based Arshia Fatima Haq, who works with the collective Discostan and as performance artist Fanaa, is another artist from the swANA diaspora who takes a celebratory approach to resistance. Whether leading a parade of silver-veiled revellers down Hollywood Boulevard for the recent Ajnabi Milan (Stranger's Union) (2019) with artist and fashion designer Hushi Mortezaie, or gold-leafing a rapidly melting ice sculpture of Buraq, the Koranic steed of the Prophet (fig. 2), Haq embraces the ephemeral and the effervescent in her work. Darkness coexists, as when she buried herself in a mound of earth for Cyclic, Exhumed (2018) performed at the Biosphere 2 in Tucson, Arizona, site of a failed experiment in utopia built in the 1990s and underwritten by future 


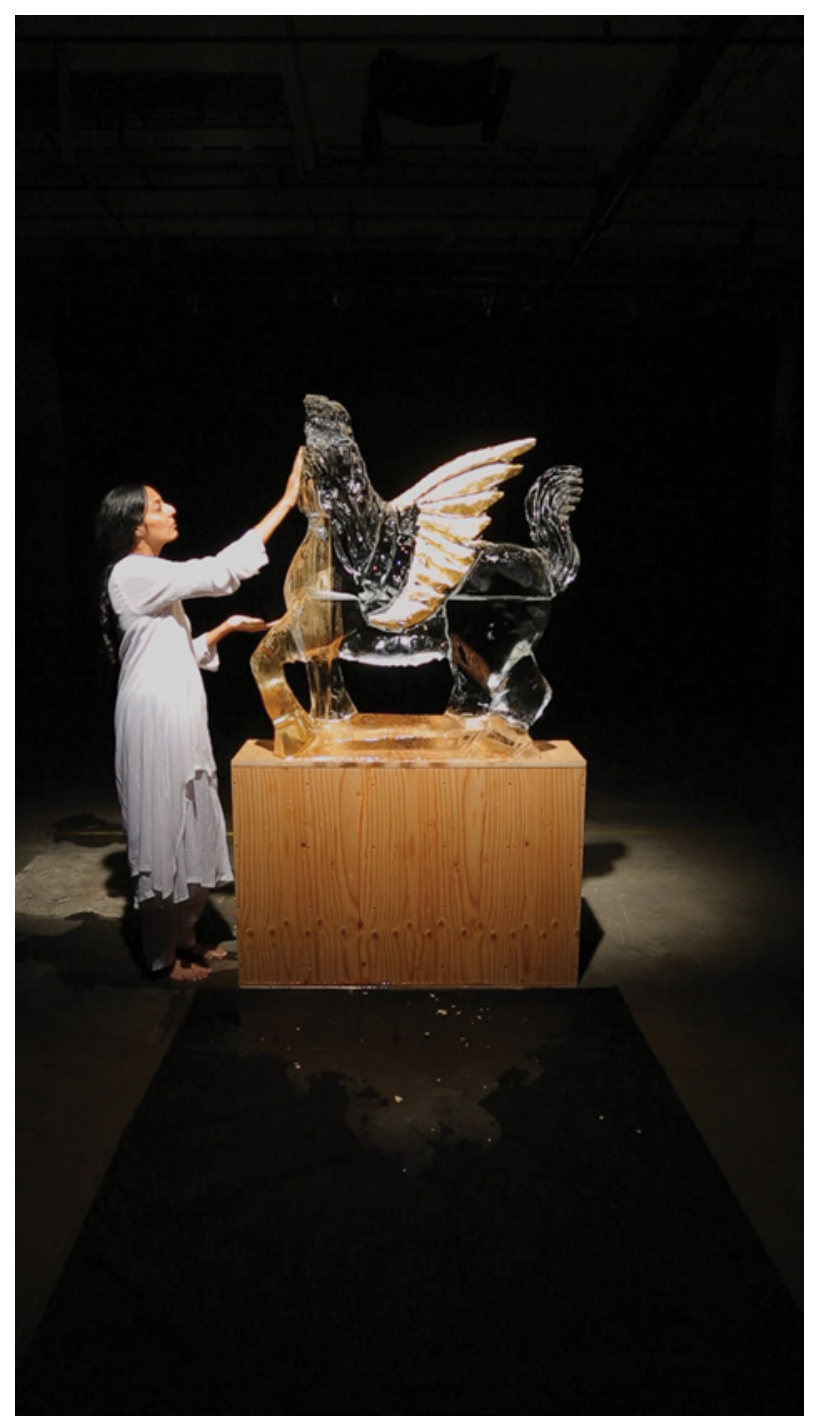

FIgURE 2 Arshia Fatima Haq, The Ascension (in collaboration with Cassils), 2018, performance (video still), ice, gold leaf, metal pulver.

IMAGE CREDIT: ALLISON KELLY.

Trump henchman Steve Bannon. The links between a colonist utopia in the desert and a white nationalist regime gone haywire are poetically invoked in the artist's representation of violence and renewal, using her own brown body as an emblem.

The work of Equality Labs founder and artist Thenmozhi Soundararajan has deeply informed the conversations that led up to this issue of ADVA. Through 
her work that includes art, advocacy, and public surveys to evaluate the ongoing effects of caste discrimination, the manipulation of social media (in the form of abuse and trolling behaviour) by a Hindu Indian community in the US desperate to maintain caste privilege has been exposed. Caste discrimination in the US and Canada has been the subject of a Pulitzer Center-funded WGBH public radio series thanks to Equality Labs' work, revealing how whitecollar Indian immigrants ignore the clear evidence of caste discrimination that keeps diasporic Dalits in disenfranchised manual labour roles. ${ }^{11}$ This series, hosted by Senior Investigative Reporter for WG BH News, Phillip Martin, underscores the necessity of solidarity across African American and South Asian diasporic political networks to eradicate this violent system of forced labour and oppression.

Given that the contemporary art world is already highly stratified by class, the introduction of largely invisible caste discrimination at all levels, from immigration to school admissions to social networks, further limits access. Artists whose trajectories intersect with other, more visible categories of identity are affected by this to a lesser extent. South Asians who are Muslim or whose families emigrated to the West via African countries such as Kenya or Uganda are more legible in a global art market that understands artists of colour only according to the conditions of their marginalization vis-à-vis the West. Of course, privilege knows no colour, and high-caste, economically well-off Indians experience as many internal as external barriers to their participation in an art system which leverages social capital in the service of financial gain.

Representatives of underserved communities are expected to speak for the most deprived from a perspective of intimate knowledge with the practices and beliefs of the global elite. Leaders who fit this mould include Nehru (Trinity College, London), Gandhi (University College, London), and even B. R. Ambedkar (Columbia University, London School of Economics), whose work is too little discussed among mainstream South Asians in the US. Ambedkar was educated in the early twentieth century at Elphinstone College at the University of Bombay, a school established by the colonial Bombay Native Education Society at the peak of the British Raj in 1824. His ability to have a political voice - to speak as the subaltern, in Spivak's construction-was established by his participation in these Western institutions, and their ensuing sanction. In fact, Ambedkar argues with Gandhi about the latter's failure to

\footnotetext{
11 "Phillip Martin Hosts Panel Discussion on 'Caste in America," Pulitzer Center, 22 March 2019, audio, 1:04:28, https://pulitzercenter.org/reporting/phillip-martin-hosts-panel -discussion-caste-america/.
} 
sufficiently advocate for full civil rights for Dalit citizens using thinkers from the Western Enlightenment to make his point. Ambedkar actually argues against an "indigenous" Hindu legal code for the new India, advocating instead for Western law that while coercive, still represents a counterweight that can be wielded against the cruelties and degradations of the caste system that he asserts are baked into Hindu legal and philosophical texts. ${ }^{12}$

This is reflective of the ongoing lineage of colonialism as well as the intimate connections between the politics of the subcontinent and the experience of diaspora which inform the whole construction of globalism, and South Asian artists' relationship to it. At times, we are examining and naming our own privilege as Savarna, Hindu, Brahmin, light-complected, or North Indian; at others, we are holding space for marginalized voices from within our multifaceted community. We reflect on the histories of the subcontinent that set trajectories in motion which would ultimately bring us to the Americas - the abolition of African slavery in Britain in 1833 and the subsequent introduction of bonded Indian labourers into the Caribbean, South America, and colonial Africa, ${ }^{13}$ and the Partition of India and Pakistan in 1947, which internally displaced up to 14 million people on the subcontinent. ${ }^{14}$ We acknowledge how discrimination has kept our long history in the Americas a secret, forcing South Asians to disappear for safety..$^{15}$ We notice how both white and Black Americans appropriate aspects of our culture such as yoga, meditation, and mysticism as a means of advancing their own freedom, and how queer Orientalism functions for us as a code-switching device. For this issue of ADVA, we have sought to raise these unspoken questions of hierarchy and privilege within a shared South Asian identity space.

12 B. R. Ambedkar, "Appendix II: A Reply to the Mahatma by Dr. B. R. Ambedkar." Annihilation of Caste," (Mumbai: B. R. Ambedkar institute of Social and Economic Change, 1944 [reprint from third edition]), 56 .

13 Sundari Anitha and Ruth Pearson, "Migration: Indentured Labor from South Asia (18341917)," in Striking Women (Lincoln: University of Lincoln, 2013), https://www.strikingwomen.org/module/map-major-south-asian-migration-flows/indentured-labour-southasia-1834-1917 (accessed 7 April 2019).

14 William Dalrymple, "The Great Divide: The Violent Legacy of Indian Partition," The New Yorker, 22 June 2015, https://www.newyorker.com/magazine/2015/o6/29/the-great-divide -books-dalrymple.

15 Vivek Bald, Bengali Harlem and the Lost Histories of South Asian America (Cambridge: Harvard University Press, 2015). 


\section{Anuradha Vikram (Co-Guest Editor)}

is a curator, writer, and educator whose book Decolonizing Culture (Art Practical/Sming Sming Books, 2017) addresses questions of race and gender parity in contemporary art spaces. Vikram is Artistic Director at 18th Street Arts Center, Senior Lecturer at Otis College of Art and Design, and a member of the Board of Directors of the College Art Association. She is a New York-born, first-generation Indian American living in Los Angeles.

\section{Jaishri Abichandani (Co-Guest Editor)}

is an artist and organizer who served as the Founding Director of Public Events and Projects at the Queens Museum from 2003-2006. She has organized exhibitions including Fatal Love: South Asian American Art Now, Queens International 2006, and cocurated Lucid Dreams and Distant Visions (Asia Society, 2017) as well as the inaugural trio of exhibitions for the Ford Foundation Gallery at the Ford Foundation Center for Social Justice in 2019. She is the founder of the South Asian Womens' Creative Collective in New York and London. Abichandani was born in Bombay, India, and lives in New York.

\section{Santhi Kavuri-Bauer (Co-Guest Editor)}

is an Associate Professor of art history at San Francisco State University, where she teaches Asian American art, modern and contemporary Asian art, and the art and architecture of South Asia. Recent projects include the articles, "Colors in Motion: The New York Paintings of Natvar Bhavsar," in Third Text, and "The Art of Hydrarchy: Asian American Art as Maritime Critique and Utopian Gesture", in Asian Diasporic Visual Cultures and the Americas; and the exhibition Mashrabiya: The Art of Looking Back (2017) at the Fine Arts Gallery of San Francisco State University, featuring six California-based artists whose work directly or indirectly engages with Middle Eastern culture, history, politics, and artistic traditions.

\section{References}

Ambedkar, B.R. “Appendix II: A Reply to the Mahatma by Dr. B. R. Ambedkar.” In Annihilation of Caste. Mumbai: B.R. Ambedkar institute of Social and Economic Change, 1944 [reprint from third edition]. 56.

Anitha, Sundari and Ruth Pearson. "Migration: Indentured Labor from South Asia (1834-1917)." In Striking Women. Lincoln: University of Lincoln, 2013. [Online] https:// www.striking-women.org/module/map-major-south-asian-migration-flows/ indentured-labour-south-asia-1834-1917.

Bald, Vivek. Bengali Harlem and the Lost Histories of South Asian America. Cambridge: Harvard University Press, 2015. 
Bazelton, Lara. “Kamala Harris Was Not a 'Progressive Prosecutor.” The New York Times, 17 January 2019. https://www.nytimes.com/2019/01/17/opinion/kamala-harriscriminal-justice.html.

Bhabha, Homi K. The Location of Culture. London, New York: Routledge, 1994.

Bowles, Nellie. "Billionaire's Fight to Close Path to a California Beach Comes to a Dead End." The New York Times, 1 October 2018. https://www.nytimes.com/2018/10/o1/ technology/california-beach-access-khosla.html.

Dalrymple, William. "The Great Divide: The Violent Legacy of Indian Partition." The New Yorker, 22 June 2015. https://www.newyorker.com/magazine/2015/06/29/ the-great-divide-books-dalrymple.

GSAFE. "A Timeline of Lesbian, Gay, Bisexual, and Transgender History in the United States." LGBT History Materials. Accessed 23 April 2019. https://www.gsafewi.org/ wp-content/uploads/US-LGBT-Timeline-UPDATED.pdf.

Martin, Phillip. "Phillip Martin Hosts Panel Discussion on 'Caste in America.” Pulitzer Center, 22 March 2019. Audio, 1:04:28. https://pulitzercenter.org/reporting/ phillip-martin-hosts-panel-discussion-caste-america.

Schulman, Sarah. "1.I have no opinion as yet about a Democratic candidate, but I do have feelings about the gay aspect of the Buttigieg candidacy." Twitter Post. 17 April 2019, 4:40 AM. https://twitter.com/sarahschulman3/status/1118479397659578368.

Sorkin, Andrew Ross. "Rajat Gupta Is Unrepentant for His Crimes." The New York Times, 22 March 2019. https://www.nytimes.com/2019/03/22/business/dealbook/rajatgupta-unrepentant.html.

Steyerl, Hito. "In Defense of the Poor Image." e-flux journal 10 (November 2009). https:// www.e-flux.com/journal/10/61362/in-defense-of-the-poor-image/.

Studio Museum Harlem. "Frequency." Accessed 23 April 2019, https://www.studiomuseum.org/exhibition/frequency.

Tolan, Casey. "How Kamala Harris' Immigrant Parents Shaped Her Life-and Her Political Outlook." The Mercury News, 10 February 2019. https://www.mercurynews. com/2019/02/10/kamala-harris-president-parents-shyamala-gopalan-donald-harris-berkeley/.

Toure. "Toure Discusses What It Means To Be Post-Black." Interview by Michele Norris. All Things Considered. NPR, 27 September 2011. Audio, 6:31. https://www.npr .org/2011/og/27/140854965/toure-discusses-what-it-means-to-be-post-black. 